\title{
Availability and access to food in supermarkets before and during the Covid-19 pandemic in a mid-size city
}

\author{
Disponibilidade e preço de alimentos \\ em supermercados antes e durante a \\ pandemia de Covid-19 em uma cidade \\ de médio porte
}

\author{
Priscila Moreira de Lima PEREIRA ${ }^{1}$ (iD) 0000-0002-7983-6307 \\ Pollyana Ferreira PEREIRA' ${ }^{1}$ (D) 0000-0003-1917-7714 \\ Mariana Lamha CASTELLÕES ${ }^{1}$ (iD) 0000-0003-1960-9396 \\ Ramon Simonis PEQUENO ${ }^{1}$ (iD) 0000-0002-7651-8688 \\ Mário Círio NOGUEIRA² (iD 0000-0001-9688-4557 \\ Ana Paula Carlos CÂNDIDO' (iD) 0000-0002-1481-5927
}

A B S TRACT

\section{Objective}

To investigate the availability and price of fresh and ultra-processed foods in supermarkets before and during the Covid-19 pandemic in a mid-size city in the Brazilian state of Minas Gerais.

\footnotetext{
${ }^{1}$ Universidade Federal de Juiz de Fora, Instituto de Ciências Biológicas, Departamento de Nutrição. R. José Lourenço Kelmer, s/n., São Pedro, 36036-900, Juiz de Fora, MG, Brasil. Correspondence to: A.P.C CANDIDO. E-mail: <anapaula.candido@uff.edu.br>.

${ }^{2}$ Universidade Federal de Juiz de Fora, Faculdade de Medicina, Departamento de Saúde Coletiva. Juiz de Fora, MG, Brasil. Support: Coordenação de Aperfeiçoamento de Pessoal de Nível Superior (CAPES, Coordination for the Improvement of Higher Education Personnel).
}

\footnotetext{
How to cite this article

Pereira PML, Pereira PF, Castellóes ML, Pequeno RS, Nogueira MC, Cândido APC. Availability and access to food in supermarkets before and during the Covid-19 pandemic in a mid-size city. Rev Nutr. 2021;34:e210006. https://doi.org/10.1590/1678-9865202134e210006
} 


\section{Methods}

Ecological and longitudinal study. A proportionate stratified random sampling method was applied to supermarkets in the municipality. To assess the availability, variety, and price of fresh and ultra-processed foods, we applied the Estudo do Ambiente Obesogênico em São Paulo (ESAO, Obesogenic Environment Study in São Paulo, Brazil) Food Store Observation Tool questionnaire and calculated the Healthy Food Store Index. The audits took place from December 2019 to January 2020, and we returned to the establishments in September 2020. Descriptive analyzes, McNemar tests, paired Student's T or Wilcoxon tests were performed using the SPSS software, version 20.0, with a 5\% significance level.

\section{Results}

Ten supermarkets were evaluated. The prices of oranges $(p=0.012)$, bananas $(p=0.043)$, apples $(p=0.004)$, and onions $(p=0.004)$ were significantly increased during the time frame. Sugar-free soft drinks $(p=0.044)$, powdered drinks $(p=0.032)$, and corn snacks $(p=0.015)$ showed a greater variety of brands and flavors during the pandemic. The Healthy Food Store Index score was $9.50 \pm 0.85$ before the pandemic and $9.00 \pm 1.15$ during it.

\section{Conclusion}

The prices of some fruits and vegetables increased, and supermarkets sold a greater variety of ultra-processed foods. Such findings highlight the importance of assessing the consequences of the Covid-19 pandemic on the food environment.

Keywords: Food and Nutrition Security. Food Production. Food supply. Food. Infections.

\section{RESUMO}

\section{Objetivo}

Investigar a disponibilidade e preço de alimentos in natura e ultraprocessados em supermercados no período anterior e durante a pandemia de Covid-19 em uma cidade de médio porte de Minas Gerais.

\section{Métodos}

Estudo ecológico e longitudinal. Realizou-se amostragem aleatória estratificada proporcional dos supermercados do município. Foi aplicado o questionário ESAO Food Store Observation Tool, o qual avalia a disponibilidade, variedade e preço de alimentos in natura e ultraprocessados, e calculou-se o índice Healthy Food Store Index. As auditorias ocorreram nos meses de dezembro de 2019 e janeiro de 2020 e retornou-se aos estabelecimentos em setembro de 2020. Foram realizados análises descritivas, testes de McNemar, T de Student pareado ou Wilcoxon utilizando-se o software SPSS, versão 20.0, com nível de significância de 5\%.

\section{Resultados}

Foram avaliados dez supermercados. Os preços da laranja $(p=0,012)$, banana $(p=0,043)$, maçã $(p=0,004)$ e cebola $(p=0,004)$ apresentaram aumento significativo, e uma variedade maior de marcas e sabores de refrigerantes sem açúcar $(p=0,044)$, refresco em pó $(p=0,032)$ e salgadinhos de milho $(p=0,015)$ foram encontradas durante a pandemia. $A$ pontuação do índice Healthy Food Store Index antes da pandemia foi de 9,50 0 0,85 e durante a pandemia foi de 9,00 $\pm 1,15$.

\section{Conclusão}

Foram verificados aumentos nos preços de frutas e legumes e uma maior variedade de alimentos ultraprocessados disponíveis na auditoria feita durante a pandemia. Esses achados contribuem para salientar a importância da avaliação das consequências da pandemia de covid-19 no ambiente alimentar.

Palavras-chave: Segurança Alimentar e Nutricional. Abastecimento de alimentos. Alimentos. Infecções.

\section{INTRODUCTION}

The pandemic of COVID-19, caused by the SARS-CoV-2 virus, and the actions aiming to reduce the propagation of the virus such as social distancing, closure of non-essential economic activities, and reduction of commercial transportation have impacted food systems, adversely affecting the quantity, quality, accessibility, and price of the food available for consumption [1-3]. These circumstances have implications on food security, eating practices, and the nutritional situation of populations $[4,5,6]$. 
Changes in eating patterns are expected during the pandemic. As restaurants, bars, and other eating places stop working, schools close, and social distancing measures lead more people to work at home, a growing number of meals are likely to occur at home $[7,8]$. Besides, to reduce the number of shopping trips and overall social exposure, families tend to buy larger amounts of non-perishable food items [9].

Growing levels of stress and depression, along with reduced cooking abilities, may further influence the types and amounts of food obtained. That leads to an expanding preference for ultra-processed foods, which are low-cost and less healthy [10-12]. For instance, a recent review Matsuo et al., [13] identified changes in people's eating patterns during the pandemic, such as increasing consumption of high-energy dense foods with high levels of sugar and fat (sweets, sugary drinks, and salty snacks).

Eating habits are also influenced by the food environment, the consumer's interface with the food system to acquire the foods they consume. Thus, evaluating the establishments that sell food and the information on food availability, variety, promotion, and prices help identify facilitators or inhibitors of healthy behaviors [14].

Supermarkets have been considered the most relevant places to shop for food in Brazil, developing into a preference in many other countries during the pandemic [15-17]. That inclination may be justified by these stores' convenience, gathering different food services (butchery, fruits and vegetables, and bakery, among others), as well as by their larger supplies, quality, and lower prices when compared with other commercial spaces. Additionally, supermarkets have adopted strategies to make food production and distribution safer and easier, like reinforcing good hygiene and sanitation practices in the stores and using delivery applications [15].

The current scenario of the food sector and the possible impacts of the pandemic in producing, distributing, and commercializing food are still uncertain. Notwithstanding, research on that issue remains scarce in Brazil. Therefore, the present study investigates the availability and price of fresh and ultra-processed foods in supermarkets in a mid-size city in the state of Minas Gerais before and during the pandemic.

\section{METHODS}

This is an ecological longitudinal study that evaluated food availability and price in supermarkets before and during the Covid-19 pandemic in a mid-size city in Minas Gerais, Brazil [18].

We began the empirical research by contacting the Coordination of Economic and Tax Information, the Superintendency of Tax Revenue and Information, and the Minas Gerais State Treasury Office. As a result, we were allowed to access a sheet with the taxpayers' roll, which provided the registration data of the commercial places in the city (Corporate name, commercial name, full address, and entry in the Classificação Nacional de Atividades Econômicas - CNAE, National Classification of Economic Activities). We used that information to build a database with food-selling establishments categorized by the CNAE, which groups establishments into the following classes: butcheries and fish markets; retail stores specialized in sweets, candies, chocolates, and similar; horticultural produce and groceries; hypermarkets and supermarkets; cafeterias, snack houses, tea and juice houses, and similar; among others.

To select establishments for the audits, we applied a proportionate stratified random sampling technique to the supermarkets in the municipality. The sample calculation was performed with the software Epi InfoTM (version 7.2.2.6, Centers for Disease Control and Prevention, US), adopting: (1) a total of 4,788 establishments that sold food in the city; (2) a hypothetical frequency for the unknown outcome in the population (50\%); (3) a 5\% confidence limit; (4) effect of design of 1; and (5) a 95\% confidence interval. Afterward, a proportionate stratification method was classified the stores by their location in the city's administrative regions (North, Northeast, Central, East, West, Southeast) and to their activities described in CNAE. The research only included supermarkets and hypermarkets, which account for $1.5 \%(n=74)$ of 
the number of food stores in the city. As per the sample calculation previously described, the sample was comprised of 10 supermarkets. The establishments were randomly picked. Inconsistent entries, such as nonexistent or wrongly categorized stores, were replaced by the next selected one on the list.

The audits were carried out with the Estudo do Ambiente Obesogênico em São Paulo (ESAO, Obesogenic Environment Study in São Paulo, Brazil) Food Store Observation Tool (ESAO-S). The items included in the questionnaire are some of the most bought and consumed by Brazilian people, including fruits (orange, banana, papaya, apple, watermelon, bergamot/tangerine, mango, pineapple, lemon, and grapes), vegetables and leaves (tomato, onion, carrot, lettuce, zucchini, bell peppers, cabbage, cucumber, eggplant, chayote), and ultra-processed foods (sodas, Tetra Pak juices and nectars, powdered drinks, sandwich cookies, and corn snacks). The research evaluated these items' availability and variety, and the price of the four most-cited fruits and four most-cited vegetables and leaves, as well as of some of the ultra-processed foods. For the price evaluation, we examined the smallest price found for the product [19].

To evaluate the access to healthy foods in the analyzed stores, we calculated the Healthy Food Store Index (HFSI). The HFSI is used to assign a score to ESAO-S. It counts 1 to 16 points and measures the availability, variety, and propaganda or promotion of healthy foods (fruits and vegetables/leaves) and ultra-processed foods considered unhealthy (sugary drinks, chocolate sandwich cookies, corn snacks). In the index, healthy foods fare positively, and unhealthy foods fare negatively. Availability is determined by the existence (or not) of at least one variety of the evaluated food items. The variety of fruits and vegetables is represented by punctuation ranging between 0 (absent), 1 ( 1 to 14 sorts available), and 2 (15 or more sorts available). The higher the HFSI punctuation, the more accessible healthy foods are [20].

Most audits happened in December 2019 and January 2020, before the Covid-19 pandemic reached Brazil, and we returned to the same stores roughly six months after quarantine measures started, in September 2020. The research was carried out by a graduate student assisted by scientific initiation fellows properly trained to apply the instrument. We used the stores' addresses to find their geographical coordinates (longitude and latitude), georeferenced the areas, and built a thematic map using the program QGIS (version 2.8.6, Boston, USA).

To analyze the data, we first verified the consistency and integrity of the database. Afterward, we evaluated the normality of continuous variables with the Shapiro-Wilk test and visual inspections of the frequency histograms. Information on the availability, variety, and prices of foods, as well as on HFSI indexes, was described by absolute and relative frequencies, measures of central tendency (mean or median), and values of dispersion (standard deviation or minimum and maximum values). The categorical variables were compared using the McNemar test. The means or medians at the two moments were compared with paired Student's T test or Wilcoxon test, respectively. Statistical analyses were carried out with the software SPSS ${ }^{\circledR}$ (Version 20.0; SPSS Inc., USA) with a significance level of $5 \%(p<0.05)$.

\section{RESULTS}

We evaluated ten supermarkets distributed in the city's areas. The sampling was stratified and proportionate to the number of stores in each area. Thus, participated in the audit: two supermarkets of the central area, two of the north, two of the west, one of the east, one of the northeast, and one of the south (Figure 1).

All the audited stores sold fruits, vegetables, and leaves, and these sections were not close to the main entry in any of the cases. We did not find significant variations in the availability and variety of fruits, vegetables, and leaves from the first period of the research to the second. As to their costs, mean or median values of several foods tended to increase, but the growth was only significant for oranges $(p=0.012)$, bananas $(p=0.043)$, apples $(p=0.004)$, and onions $(p=0.004)$ (Table 1$)$. 


\section{Caption}

- Supermarkets

Areas of the city

Center

East

Northeast

North

West

Southeast

South

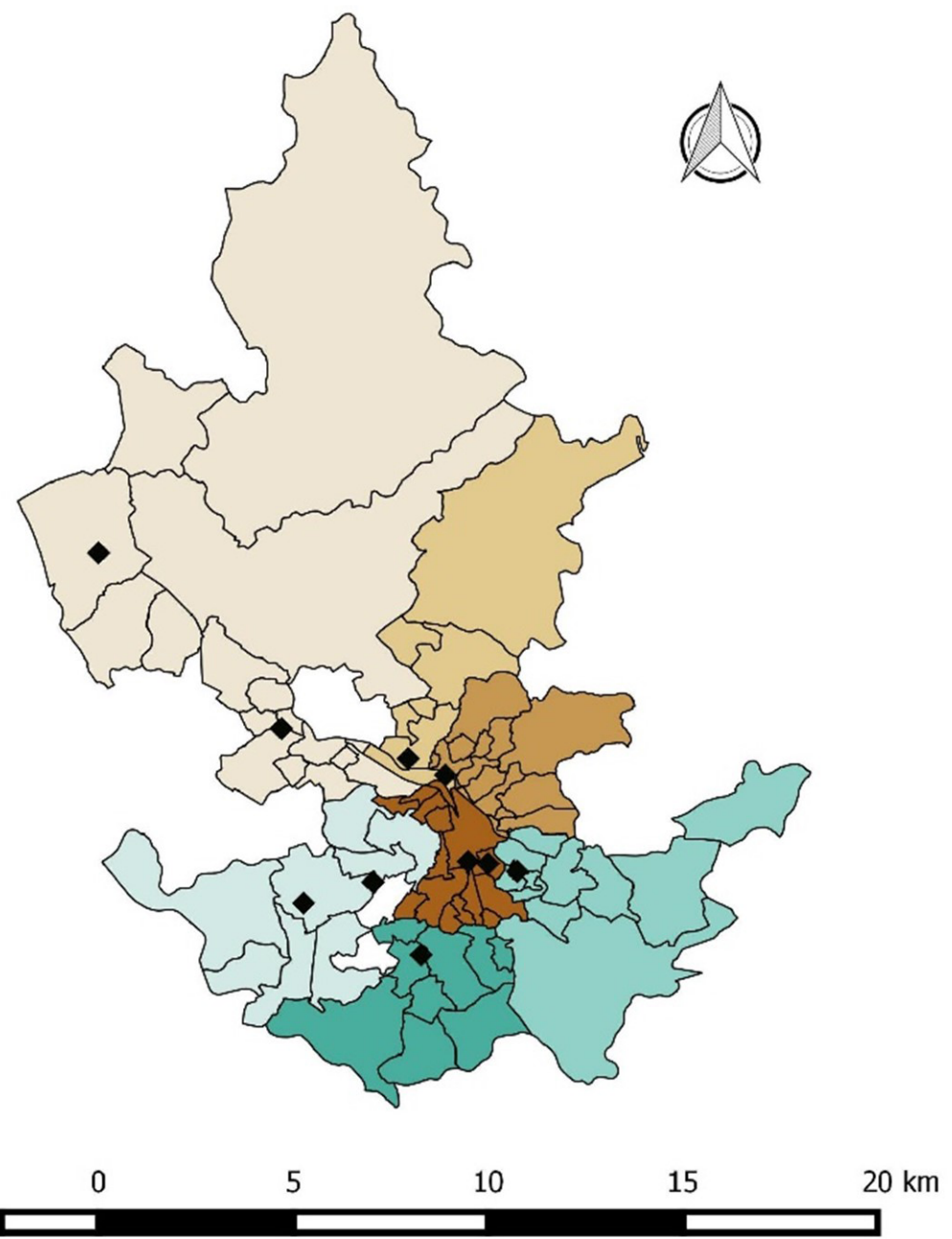

Figure 1 - Space distribution of the supermarkets audited in a mid-size city in Minas Gerais.

As for the availability, variety, and prices of ultra-processed foods, we found a rising number of brands available for sugar-free sodas ( $p=0.044)$, powdered drinks $(p=0.032)$ and corn snacks in packages from 30 to 60 grams $(p=0.015)$. No significant variations were identified in the prices of these foods (Table 2 ).

Finally, the total number of different types and varieties of fruits and vegetables did not change significantly before and during the pandemic. The HFSI punctuation before the pandemic was $9.50 \pm 0.85$, and during the pandemic, it was 9.00 \pm 1.15 (Table 3).

\section{DISCUSSION}

The present study did not find any significant differences regarding the availability and variety of fruits, vegetables, and leaves during the period assessed. The prices of a few foods like oranges, bananas, apples, and onions increased. A larger variety of brands and flavors of ultra-processed foods like sugar-free sodas, powdered drinks, and corn snacks was found during the pandemic. Differently from some natural foods, the prices of ultra-processed foods did not present important variations. Prior to the pandemic, their HFSI score was $9.50 \pm 0.85$, and during it, it is $9.00 \pm 1.15$. 
Table 1 - Availability, variety, and prices of fruits, vegetables, and leaves in supermarkets of a mid-size city in Minas Gerais before and during the Covid-19 pandemic, 2020.

\begin{tabular}{|c|c|c|c|c|c|c|}
\hline \multirow{2}{*}{$\begin{array}{l}\text { Product } \\
\text { Orange }\end{array}$} & \multirow[b]{2}{*}{ Availability } & \multicolumn{2}{|c|}{ Before the pandemic } & \multicolumn{2}{|c|}{ During the pandemic } & \multirow{2}{*}{$\frac{p \text { value }}{1.000^{\mathrm{a}}}$} \\
\hline & & 10 & $100 \%$ & 10 & $100 \%$ & \\
\hline & Number of sorts & 2 & $1-2$ & 2 & $1-3$ & $1.00^{\mathrm{b}}$ \\
\hline & Smallest value found (Brazilian Reais - BRL) & 2.69 & $1.99-3.69$ & 3.65 & $2.79-4.59$ & $0.012^{b}$ \\
\hline \multirow[t]{3}{*}{ Banana } & Availability & 10 & $100 \%$ & 10 & $100 \%$ & $1.000^{\mathrm{a}}$ \\
\hline & Number of sorts & 2 & $2-4$ & 2 & $2-4$ & $0.783^{b}$ \\
\hline & Smallest value (BRL) & 2.99 & $1.99-3.99$ & 3.99 & $2.98-5.49$ & $0.043^{b}$ \\
\hline \multirow[t]{3}{*}{ Papaya } & Availability & 10 & $100 \%$ & 9 & $90 \%$ & 1.000 \\
\hline & Number of sorts & 2 & $1-2$ & 2 & $1-2$ & $0.180^{b}$ \\
\hline & Smallest value per kilo (BRL) & $3.24 \pm 0.66$ & & $3.63 \pm 0.88$ & & $0.336^{c}$ \\
\hline \multirow[t]{3}{*}{ Apple } & Availability & 10 & $100 \%$ & 10 & $100 \%$ & $1.000^{\mathrm{a}}$ \\
\hline & Number of sorts & 3 & $1-3$ & 3 & $2-4$ & $0.705^{b}$ \\
\hline & Smallest value per kilo (BRL) & $4.64 \pm 1.66$ & & $7.49 \pm 1.88$ & & $0.004^{c}$ \\
\hline \multirow[t]{2}{*}{ Watermelon } & Availability & 9 & $90 \%$ & 10 & $100 \%$ & $0.343^{\mathrm{a}}$ \\
\hline & Number of sorts & 1 & $1-2$ & 1 & $1-1$ & $0.317^{b}$ \\
\hline Bergamot/ & Availability & 3 & $30 \%$ & 6 & $60 \%$ & $0.453^{\mathrm{a}}$ \\
\hline tangerine & Number of sorts & 1 & $1-1$ & 1 & $1-1$ & $1.000^{\mathrm{b}}$ \\
\hline \multirow[t]{2}{*}{ Mango } & Availability & 10 & $100 \%$ & 10 & $100 \%$ & $1.000^{\mathrm{a}}$ \\
\hline & Number of sorts & 1 & $1-2$ & 1 & $1-2$ & $1.00^{\mathrm{b}}$ \\
\hline \multirow[t]{2}{*}{ Pineapple } & Availability & 10 & $100 \%$ & 10 & $100 \%$ & $1.000^{\mathrm{a}}$ \\
\hline & Number of sorts & 1 & $1-1$ & 1 & $1-1$ & $1.00^{\mathrm{b}}$ \\
\hline \multirow[t]{2}{*}{ Lemon } & Availability & 10 & $100 \%$ & 10 & $100 \%$ & $1.000^{\mathrm{a}}$ \\
\hline & Number of sorts & 1 & $1-2$ & 1 & $1-2$ & $0.414^{b}$ \\
\hline \multirow[t]{2}{*}{ Grapes } & Availability & 10 & $100 \%$ & 10 & $100 \%$ & $1.000^{\mathrm{a}}$ \\
\hline & Number of sorts & 2 & $2-5$ & 3 & $2-5$ & $0.160^{b}$ \\
\hline \multirow[t]{3}{*}{ Tomato } & Availability & 9 & $90 \%$ & 10 & $100 \%$ & $0.343^{\mathrm{a}}$ \\
\hline & Number of sorts & 2 & $1-2$ & 1 & $1-3$ & $0.180^{b}$ \\
\hline & Smallest value per kilo (BRL) & $4.64 \pm 1.34$ & & $5.23 \pm 0.72$ & & 0.129 \\
\hline \multirow[t]{3}{*}{ Onion } & Availability & 10 & $100 \%$ & 10 & $100 \%$ & $1.000^{\mathrm{a}}$ \\
\hline & Number of sorts & 2 & $1-2$ & 1.5 & $1-2$ & $0.655^{b}$ \\
\hline & Smallest value per kilo (BRL) & $3.38 \pm 0.76$ & & $4.79 \pm 1.03$ & & $0.004^{c}$ \\
\hline \multirow[t]{3}{*}{ Carrot } & Availability & 10 & $100 \%$ & 10 & $100 \%$ & $1.000^{\mathrm{a}}$ \\
\hline & Number of sorts & 1 & $1-1$ & 1 & $1-1$ & $1.000^{\mathrm{b}}$ \\
\hline & Smallest value per kilo (BRL) & $4.08 \pm 1.22$ & & $3.68 \pm 1.19$ & & $0.361^{c}$ \\
\hline \multirow[t]{3}{*}{ Lettuce } & Availability & 9 & $90 \%$ & 10 & $100 \%$ & $0.343^{a}$ \\
\hline & Number of sorts & 2 & $1-3$ & 2 & $1-4$ & $0.157^{b}$ \\
\hline & Smallest value per unity (BRL) & 1.99 & $1.29-2.79$ & 2.49 & $1.29-2.99$ & $0.138^{b}$ \\
\hline \multirow[t]{2}{*}{ Zucchini } & Availability & 10 & $100 \%$ & 10 & $100 \%$ & $0.343^{\mathrm{a}}$ \\
\hline & Number of sorts & 1 & $1-1$ & 1 & $1-1$ & $1.000^{\mathrm{b}}$ \\
\hline \multirow[t]{2}{*}{ Bell Pepper } & Availability & 10 & $100 \%$ & 10 & $100 \%$ & $1.000^{\mathrm{a}}$ \\
\hline & Number of sorts & 3 & $1-3$ & 3 & $1-3$ & $0.566^{b}$ \\
\hline \multirow[t]{2}{*}{ Cabbage } & Availability & 9 & $90 \%$ & 10 & $100 \%$ & $0.343^{\mathrm{a}}$ \\
\hline & Number of sorts & 2 & $1-2$ & 2 & $1-2$ & $1.000^{\mathrm{b}}$ \\
\hline \multirow[t]{2}{*}{ Cucumber } & Availability & 10 & $100 \%$ & 10 & $100 \%$ & $1.000^{\mathrm{a}}$ \\
\hline & Number of sorts & 1.5 & $1-2$ & 1 & $1-2$ & $0.564^{b}$ \\
\hline Eggplant & Availability & 9 & $90 \%$ & 10 & $100 \%$ & $0.343^{a}$ \\
\hline & Number of sorts & 1 & $1-1$ & 1 & $1-1$ & $1.000^{\mathrm{b}}$ \\
\hline Chayote & Availability & 9 & $90 \%$ & 9 & $90 \%$ & $1.000^{\mathrm{a}}$ \\
\hline & Number of sorts & 1 & $1-1$ & 1 & $1-1$ & $1.000^{\mathrm{b}}$ \\
\hline
\end{tabular}

Note: ${ }^{a}$ McNemar Test; 'Wilcoxon Test; 'Student's T Test. Availability: Absolute and relative frequencies of establishments where the food is present. Variety: Mean or median number of varieties of the food in supermarkets. 
Tabela 2 - Availability, variety, and prices of ultra-processed foods in supermarkets of a mid-size city in Minas Gerais before and during the COVID-19 pandemic, 2020.

\begin{tabular}{|c|c|c|c|c|c|c|}
\hline \multirow{3}{*}{$\begin{array}{l}\text { Products } \\
\text { Coke }(350 \mathrm{ml} \text { can })\end{array}$} & \multirow[b]{2}{*}{ Availability } & \multicolumn{2}{|c|}{ Before the pandemic } & \multicolumn{2}{|c|}{ During the pandemic } & \multirow{2}{*}{$\frac{p \text { value }}{1,000^{a}}$} \\
\hline & & 10 & $100 \%$ & 10 & $100 \%$ & \\
\hline & Smallest value found (BRL) & 2.69 & $2.49-3.99$ & 2.67 & $2.49-3.19$ & $0.271^{b}$ \\
\hline \multirow{2}{*}{ Coke Zero (350ml can) } & Availability & 8 & $80 \%$ & 9 & $90 \%$ & $1.000^{\mathrm{a}}$ \\
\hline & Smallest value (BRL) & 2.69 & $2.49-3.69$ & 2.67 & $2.29-3.19$ & $0.109^{b}$ \\
\hline \multirow{2}{*}{ Cola soft drink ( $350 \mathrm{ml}$ can) } & Number of brands & 2 & $1-3$ & 2 & $2-3$ & $0.317^{b}$ \\
\hline & Smallest value (BRL) & 2.59 & $2.45-3.15$ & 2.55 & $1.85-3.19$ & $0.345^{b}$ \\
\hline \multirow{2}{*}{$\begin{array}{l}\text { Sugar-free cola soft drink } \\
(350 \mathrm{ml} \text { can) }\end{array}$} & Number of brands & 2 & $1-3$ & 2 & $1-3$ & $1.000^{b}$ \\
\hline & Smallest value (BRL) & 2.65 & $1.99-3.15$ & 2.55 & $1.99-3.19$ & $0.600^{b}$ \\
\hline Regular sodas/soft drinks & $\begin{array}{l}\text { Number of brands and flavors } \\
\text { available }\end{array}$ & $15.10 \pm 3.14$ & & $17.40 \pm 4.69$ & & 0.109 \\
\hline Sugar-free sodas/soft drinks & $\begin{array}{l}\text { Number of brands and flavors } \\
\text { available }\end{array}$ & 2 & $1-6$ & 4 & $3-7$ & $0.044^{b}$ \\
\hline \multirow{2}{*}{ Tetra Pak Juices or Nectars } & Number of brands & $7.10 \pm 2.51$ & & $7.90 \pm 2.23$ & & $0.070^{c}$ \\
\hline & Smallest value (BRL) & $2.29 \pm 0.90$ & & $2.25 \pm 1.12$ & & $0.932^{c}$ \\
\hline \multirow{2}{*}{ Powdered drinks } & Number of brands & $5.20 \pm 0.92$ & & $6.20 \pm 1.69$ & & $0.032^{c}$ \\
\hline & Smallest value (BRL) & 0.69 & $0.49-0.99$ & 0.59 & $0.39-0.99$ & $0.593^{b}$ \\
\hline \multirow{2}{*}{$\begin{array}{l}\text { Chocolate sandwich cookies } \\
(70-165 \mathrm{~g})\end{array}$} & Number of brands & 8.5 & $6-13$ & 10.5 & $7-13$ & $0.329^{b}$ \\
\hline & Smallest value (BRL) & $1.35 \pm 0.28$ & & $1.48 \pm 0.32$ & & $0.367^{c}$ \\
\hline \multirow{2}{*}{ Corn snacks (30-60g) } & Number of brands & $5.20 \pm 2.25$ & & $8.60 \pm 4.06$ & & $0.015^{c}$ \\
\hline & Smallest value (BRL) & $1.60 \pm 0.61$ & & $1.64 \pm 0.74$ & & $0.858^{c}$ \\
\hline \multirow{2}{*}{ Corn snacks (100-170g) } & Number of brands & $6.70 \pm 2.91$ & & $7.80 \pm 4.16$ & & $0.462^{c}$ \\
\hline & Smallest value (BRL) & $2.79 \pm 1.21$ & & $2.99 \pm 1.17$ & & $0.752^{c}$ \\
\hline
\end{tabular}

Note: aMcNemar Test; bWilcoxon Test; cStudent's T Test. Availability: Absolute and relative frequencies of establishments where the food is present. Variety: Mean or median number of varieties of the food in supermarkets.

Table 3 - Evaluation of the diversity and variety of fruits, and the HFSI score of the supermarkets audited, in a mid-size city in Minas Gerais, before and during the COVID-19 pandemic, 2020.

\begin{tabular}{|c|c|c|c|c|c|}
\hline \multirow{2}{*}{$\begin{array}{l}\text { Variables } \\
\text { Different fruits }\end{array}$} & \multicolumn{2}{|c|}{ Before the pandemic } & \multicolumn{2}{|c|}{ During the pandemic } & \multirow{2}{*}{$\frac{p \text { value }}{0.317 a}$} \\
\hline & 9 & $8-10$ & 9.5 & $9-10$ & \\
\hline Variety of fruits & $17.00 \pm 2.54$ & & $17.10 \pm 2.60$ & & $0.925 b$ \\
\hline Different vegetables & 10 & $6-10$ & 10 & $9-10$ & $0.257 \mathrm{a}$ \\
\hline Vegetable Varieties & $14.10 \pm 2.42$ & & $15.20 \pm 2.57$ & & $0.389 \mathrm{~b}$ \\
\hline HFSI Score & $9.50 \pm 0.85$ & & $9.00 \pm 1.15$ & & $0.273 b$ \\
\hline
\end{tabular}

Note: aWilcoxon Test; 'bStudent's T Test.

Though the variety and availability of fruits, vegetables, and leaves were not affected in the present study, it is important to asses these results from different perspectives, chiefly for the most vulnerable. Given the pandemic and the distancing measures in place, workers are more restricted and transportation systems are sometimes interrupted, limiting the movement of agricultural inputs and foods, and hampering the logistics of supply chains $[3,5,20]$. These interruptions may inversely impact the quality, freshness, and security of food, besides compromising the access and increasing the prices of these products, threatening the population's food and nutritional security $[4,5]$.

Measures to contain Covid-19 may impact agricultural systems of different regions differently, leaving some more exposed than others. Factors like the seasons and climate, types of suppliers of agricultural inputs, and workforce (like temporary or seasonal agricultural workers), make some systems more fragile and susceptible to interruptions, affecting food in varied ways: perishable foods like fruits, vegetables, leaves, and products of animal origins may suffer more from shortage than products easily stored, like grains and vegetable oils $[5,3,21]$. 
At the beginning of 2020, global food prices showed relatively irrelevant changes, given the good grain harvests of important suppliers like Brazil, and due to the falling oil prices, reducing the costs of transportation [22]. In the long-term, there are reasons for concern. The 2008 food crisis was intensified by export prohibitions, and should those return, global prices may increase again. Even if global prices remain unaltered, local volatility may ensue. In several countries like South Africa, retail sellers have profited with panic shopping, excessively increasing the prices of foods $[3,21]$.

These circumstances have stimulated changes in consumption patterns. The Nutrinet study carried out in Brazil identified the growing consumption of healthy eating markers and stability in the consumption of unhealthy eating markers [7]. The ConVid - Behavior Survey (ConVid - Pesquisa de Comportamentos) carried out by Fundação Oswaldo Cruz (Fiocruz, Foundation Oswaldo Cruz) detected worsening eating conditions during the pandemic, with the regular consumption of fruits, vegetables, and beans falling, and growing consumption of ultra-processed foods like packed snacks, cookies, chocolates, and frozen foods [23]. Changes in eating patterns during social isolation include the portions of food ingested, number of meals, culinary habits, methods of preparation, acquisition, food availability, the general quality of food, and food-related behaviors [13].

Justifications for the unhealthy behaviors include difficulties in finding fresh foods like fruits, vegetables, and leaves, which require more frequent shopping, increases in these foods' prices, and the possible reduction of family incomes due to job losses or problems in performing some occupations $[7,24]$. The increasing consumption of ultra-processed foods may result from a series of factors, such as their broader availability and variety in stores, price stability, as found in the present study, and being non-perishable $[25,26]$. These tendencies are worthy of attention, as increased availability, acquisition, and therefore consumption of ultraprocessed foods increase the risk for conditions like obesity, hypertension, and diabetes, which in turn make Covid-19 more severe and deadlier for patients [27-32].

Mixing availability, variety, quality, and prices, audits in food stores provide a better reflection of access to food, and therefore, an improved perspective on the relations between the environment and diets [33]. Evaluating the consumer's food environment, the present study found an HFSI punctuation in supermarkets before the pandemic of $9.50 \pm 0.85$ and during the pandemic of $9.00 \pm 1.15$, values similar to those of other studies. Another study in the same city in 2016 found an average score of $8.91 \pm 1.11$ [34].

We opted to evaluate only supermarkets as these are responsible for $59 \%$ of the food consumed by Brazilian people, with retail stores ruling over the sector [35]. Evidence suggests supermarkets foster the consumption of ultra-processed foods by stimulating the purchase of new items with promotions, attractive packages, sophisticated marketing strategies, and physical allocation [36,37]. Ultra-processed foods are also available in larger packages, encouraging large-scale acquisition and allowing people to reduce their visits to stores. Consequently, the consumption of fresh foods could be inhibited $[37,38]$.

Finally, we highlight the importance of promoting shorter food supply chains to reduce the risk of scarcity, foster physical and financial availability and access, grant access to fresh and healthy foods grown locally without agrochemicals and seasonally. That promotes family farming, which plays an important role in employment and income, and is strategic for food production and improving living conditions in rural areas $[39,40]$

The study has a few limitations. First, using secondary data sources to select the stores (the taxpayers' roll), which may lead to imprecise results. Second, the food evaluated was limited to what is included in the questionnaire (ESAO-S), though using a validated instrument increases trust in the data analysis and comparability with other studies. Additionally, as we always selected the cheapest brand for the price analyses, the products compared were not identical. However, that was the methodology employed in the utilized instrument. Finally, the audits were carried out during different months and seasons, influencing food availability, variety, and price - especially for fruits and leaves. Despite that, the items that presented more significant variations in values (oranges, bananas, apples, and onions) are less subjected to season changes 
and are produced and kept with methods that make commercialization easier during different periods of the year. Also, a few of them may have price changes during the week, with supermarkets' usual daily promotions.

Even with these limitations, this is the first study to evaluate the impact of the Covid-19 pandemic in the consumer's food environment, including data referring to the availability, variety, and price of different foods before and during the pandemic. Such measures may influence areas like urban planning and food and nutritional security, and benefit the entire population.

\section{CONCLUSION}

We conclude that the availability and variety of fruits, vegetables, and leaves were not affected during the analyzed period of the Covid-19 pandemic. However, the prices of some fruits increased (oranges, bananas, apples), along with the prices of onions. Ultra-processed foods like sugar-free sodas, powdered drinks, and packaged snacks presented more brands and flavors during the pandemic, but no significant differences in prices. The access to healthy foods was not altered (the before the pandemic was $9.50 \pm 0.85$ and during the pandemic was $9.00 \pm 1.15$ ).

These results highlight the relevance of assessing the pandemic's consequences in the food environment. The discussion regarding its impacts on food availability and variety and its possible implications on food consumption and security is urgent.

\section{CONTRIBUTORS}

All the authors contributed to the conception of the project, or analysis and data interpretation; writing of the article or critical relevant content review; approval of the final version to be published. All of them are responsible for the entire work and for ensuring its precision and integrity.

\section{REFERENCIAS}

1. World Health Organization. Coronavirus Disease (COVID-19) Advice for the Public: Mythbusters. Geneva; Organization, 2020 [cited 2020 Nov. 1]. Available from: https://www.who.int/emergencies/diseases/novel-coronavirus-2019/advicefor-public/myth-busters

2. The White House (United States). Coronavirus Guidelines for America. Washigton: The White House; 2020 [cited 2020 Nov. 1] Available from: https://www.whitehouse.gov/briefings-statements/coronavirus-guidelines-america/

3. Devereux, S., Béné, C. Hoddinott, J. Conceptualising COVID-19's impact on family food security. Food Sec. 2020;12:769-72. https://doi.org/10.1007/s12571-020-01085-0

4. Food and Agriculture Organization. Urban Food Systems and COVID-19: the role of cities and local governments in responding to the emergency . Rome: Organiation; 2020 [cited 2020 Nov. 1]. Available from: http://www.fao.org/ documents/card/en/c/ca8600en

5. Food and Agriculture Organization. Responding to the impact of the COVID-19 outbreak on food value chains through efficient logistics. Rome: Organization; 2020 [cited 2020 Nov. 1]. Available from: http://www.fao.org/ policy-support/tools-and-publications/resources-details/en/c/1270169/

6. United Nations Sustainable Development Group. Policy Brief. the impact of COVID-19 on food security and nutrition. New York: United Nations; 2020 [cited 2020 Nov. 1]. Available from: https://unsdg.un.org/resources/policy-briefimpact-covid-19-food-security-and-nutrition 
7. Steele EM, Rauber F, Costa CS, Leite MA, Gabe KT, Louzada MLC, et al. Mudanças alimentares na coorte NutriNet Brasil durante a pandemia de covid-19. Rev Saúde Pública. 2020;54:91. https://doi.org/10.11606/s15188787.2020054002950

8. Oliveira TC, Abranches MV, Lana RM. (In) Segurança alimentar no contexto da pandemia por SARS-CoV-2. Cad Saúde Pública. 2020;36(4). https://doi.org/10.1590/0102-311x00055220

9. Tan M, He FJ, Macgregor GA. Obesity and covid-19: the role of the food industry. Bmj. 2020;369:m2237. https:// doi.org/10.1136/bmj.m2237

10. Feeding America (Chicago). The impact of the coronavirus on food insecurity. Chicago: Feeding America; 2020 [cited 2020 Nov. 1] Available from: https://hungerandhealth.feedingamerica.org/wp-content/uploads/2020/03/ Brief_Impact-of-Covid-on-Food-Insecurity-4.22.pdf

11. Wang C, Pan R, Wan X, Tan Y, Xu L, Ho CS, et al. Immediate psychological responses and associated factors during the initial stage of the 2019 coronavirus disease (COVID-19) epidemic among the general population in China. Int J Environ Res Public Health. 2020;17:1729. https://doi.org/10.3390/ijerph17051729

12. Uggioni PL, Elpo CMF, Geraldo APG, Fernandes AC, Mazzonetto AC, Bernardo GL. Cooking skills during the Covid-19 pandemic. Rev Nutr. 2020;33:e200172. https://doi.org/10.1590/1678-9865202033e200172

13. Matsuo LH, Tureck C, Lima LP, Hinnig PF, Trindade EBSM, Vasconcelos FAG. Impact of social isolation by Coronavirus disease 2019 in food: a narrative review. Rev. Nutr. 2021;34:e200211. https://doi.org/10.1590/1678$9865202134 \mathrm{e} 200211$

14. Downs SM, Ahmed S, Fanzo J, Herforth A. Food environment typology: advancing an expanded definition, framework, and methodological approach for improved characterization of wild, cultivated, and built food environments toward sustainable diets. Foods. 2020;9(4):532. https://doi.org/10.3390/foods9040532

15. Machado PP, Claro RM, Martins APB, Costa JC, Levy RB. Is food store type associated with the consumption of ultra-processed food and drink products in Brazil? Public Health Nutr. 2018;21(1):201-9. https://doi.org/10.1017/ S1368980017001410

16. Di Renzo L, Gualtieri P, Pivari F, Soldati L, Attinà A, Cinelli G, et al. Hábitos alimentares e mudanças no estilo de vida durante o bloqueio COVID-19: uma pesquisa italiana. J Transl Med. 2020;18:229. https://doi.org/10.1186/ s12967-020-02399-5

17. Zachary Z, Brianna F, Brianna L, Garrett P, Jade W, Alyssa D, et al. Fatores de risco relacionados à auto-quarentena e ao ganho de peso durante a pandemia de COVID-19. Obes Res Clin Pract. 2020;14(3):210-6. https://doi.org/10.1016/j. orcp.2020.05.004

18. Freire MCM, Pattussi MP. Tipos de estudos. In: Estrela C. Metodologia científica: ciência, ensino e pesquisa. 3a. ed. Porto Alegre: Artes Médicas, 2018.

19. Duran AC, Lock K, Latorre MRDO, Jaime PC. Avaliando o uso de medidas in-store em lojas de varejo de alimentos e restaurantes no Brasil. Rev Saúde Pública. 2015;49:80. https://doi.org/10.1590/S0034-8910.2015049005420

20. Duran ACFL. Ambiente alimentar urbano em São Paulo, Brasil: avaliação, desigualdades e associação com consumo alimentar. 276 f. [Tese]. São Paulo: Universidade Federal São Paulo; 2013.

21. Competition Commission (South Africa). Joint briefing to the portfolio committee on trade and industry and select committee on economic development, Small Business Development, Tourism, Employment and Labour. Pretoria: Commission; 2020 [cited 2020 Nov 1] Available from: http://www.thedtic.gov.za/wp-content/uploads/CompetitionCommission19-May-2020.pdf

22. World Bank. Brief: food security and Covid-19. Washington: Bank; 2020 [cited 2020 Nov 1]. Available from: https:// www.worldbank.org/en/topic/agriculture/brief/food-security-and-covid-19.

23. Fundação Oswaldo Cruz (Brasil). ConVid Adolescentes: pesquisa de Comportamentos. Rio de Janeiro: Fundação; 2020 [cited 2020 Nov 1]. Available from: https://convid.fiocruz.br

24. Scarmozzino F, Visioli F. Covid-19 e o subsequente bloqueio modificaram os hábitos alimentares de quase metade da população em uma amostra italiana. Foods (Basel, Suíça). 2020;9(5):675. https://doi.org/10.3390/foods9050675

25. White M, Nieto C, Barquera S. Good deeds and cheap marketing: the food industry in the time of COVID-19. Obesity (Silver Spring). 2020;28(9):1578-9. https://doi.org/10.1002/oby.22910

26. Food and Agriculture Organization of the United Nations Nutrition and food systems: a report by The High Level Panel of Experts on Food Security and Nutrition. Rome: Organization; 2017 [cited 2020 Nov 1]. Available from: http://www.fao.org/3/a-i7846e.pdf 
27. Williamson EJ, Walker AJ, Bhaskaran K, Bacon S, Bates C, Morton CE, et al. Factors associated with COVID-19-related death using OpenSAFELY. Nature. 2020;584(7821):430-6. https://doi.org/10.1038/s41586-020-2521-4

28. Ho FK, Celis-Morales, CA, Gray SR, Katikireddi SV, Niedzwiedz CL, Hastie C, et al. Modifiable and non-modifiable risk factors for COVID-19: results from UK Biobank. MedRxiv. 2020. https://doi.org/10.1101/2020.04.28.20083295

29. Simonnet A, Chetboun M, Poissy J, Raverdy V, Noulette J, Duhamel A, et al. LICORN and the Lille COVID-19 and obesity study group. high prevalence of obesity in severe acute respiratory syndrome Coronavirus-2 (SARS-CoV-2) requiring invasive mechanical ventilation. Obesity (Silver Spring). 2020;28(7):1195-9. https://doi.org/10.1002/ oby. 22831

30. Lighter J, Phillips M, Hochman S, Sterling S, Johnson D, Francois F, et al. Obesity in patients younger than 60 years is a risk factor for Covid-19 hospital admission. Clin Infect Dis. 2020;71(15):896-7. https://doi.org/10.1093/cid/ciaa415

31. Petrilli CM, Jones SA, Yang J, Rajagopalan H, O’Donnell L, Chernyak Y, et al. Factors associated with hospital admission and critical illness among 5279 people with coronavirus disease 2019 in New York City: prospective cohort study. Bmj. 2020;369:m1966. https://doi.org/10.1136/bmj.m1966

32. Huang R, Zhu L, Xue L, Liu L, Yan X, Wang J, et al. Clinical findings of patients with coronavirus disease 2019 in Jiangsu province, China: a retrospective, multi-center study. Plos Negl Trop Dis. 2020;14(5):e0008280. https://doi. org/10.1371/journal.pntd.0008280

33. Menezes MC, Diez Roux AV, Costa BVL, Lopes ACS. Individual and food environmental factors: association with diet. Public Health Nutr. 2018;21(15):2782-92. htpps://doi.org/10.1017/S1368980018001623

34. Leite MA, Assis MM, Carmo ASD, Costa BVL, Claro RM, Castro IR, et al. Is neighbourhood social deprivation in a Brazilian city associated with the availability, variety, quality and price of food in supermarkets? Public Health Nutr. 2019;22(18):3395-404. htpps://doi.org/10.1017/S1368980019002386

35. Associação Brasileira de Supermercados. Concentração de supermercados sobe para $46 \%$ no país. São Paulo: Associação; 2017 [cited 2020 Nov 1]. Available from: https://www.abrasnet.com.br/clipping.php?area=20\&clipping=21585

36. Stanton RA. Food retailers and obesity. Curr Obes Rep. 2015;4(1):54-9. https://doi.org/10.1007/s13679-014-0137-4

37. Ministério da Saúde (Brasil). Dietary Guidelines for the Brazilian Population. Brasília: Ministério; 2015 [cited 2020 Nov 1]. Available from: http://bvsms.saude.gov.br/bvs/publicacoes/dietary_guidelines_brazilian_population.pdf

38. Vedovato GM, Trude AC, Kharmats AY, Martins PA. Degree of food processing of household acquisition patterns in a Brazilian urban area is related to food buying preferences and perceived food environment. Appetite. 2015;87:296302. https://doi.org/10.1016/j.appet.2014.12.229

39. Martinelli SS, Cavalli SB, Fabri RK, Veiros MB, Reis ABC, Amparo-Santos L. Strategies for the promotion of healthy, adequate and sustainable food in Brazil in times of Covid-19. Rev Nutr. 2020;33:e200181. https://doi. org/10.1590/1678-9865202032e200181.

40. Cavalli SB, Soares P, Martinelli SS, Schneider S. Agricultura familiar na época de Covid-19. Rev Nutr. 2020;33:e200180. https://doi.org/10.1590/1678-9865202033e200180 